Prognosen ved amyopatisk og hypomyopatisk dermatomyositt avhenger av graden av interstitiell lungesykdom og eventuell forekomst av ledsagende kreftsykdom. Hudlesjonene vil hos de fleste bedres eller tilheles nærmest fullstendig (7).

\section{Konklusjon}

Ved amyopatisk og hypomyopatisk dermatomyositt utvikles typiske hudmanifestasjoner, mens symptomer og funn av muskelsykdom kan være svært beskjedne, eller mangle helt. Tilstanden bør diagnostiseres tidlig da mange pasienter utvikler behandlingstrengende interstitiell lungesykdom, og risikoen for ledsagende kreftsykdom er den samme som for klassisk dermatomyositt.

\section{Jan Tore Gran}

jan.tore.gran@rikshospitalet.no

Revmatologisk avdeling

Oslo universitetssykehus, Rikshospitalet 0027 Oslo

Pasienten har gitt samtykke til at artikkelen blir publisert.

Oppgitte interessekonflikter: Ingen

\section{Litteratur}

1. Euwer RL, Sontheimer RD. Amyopathic dermatomyositis: a review. J Invest Dermatol 1993; 100 (suppl): $124-7$.

2. Gerami P, Schope JM, McDonald L et al. A systematic review of adult-onset clinically amyopathic dermatomyositis (dermatomyositis sine myositis) a missing link within the spectrum of idiopathic inflammatory myopathies. J Am Acad Dermatol 2006; 54: 597-613.
3. Ye S, Chen XX, Lu XY et al. Adult clinically amyopathic dermatomyositis with rapid progressive interstitial lung disease: a retrospective cohort study. Clin Rheumatol 2007: 26: 1647-54.

4. Miyazaki E, Ando M. Muramatsu T et al. Early assessment of rapidly progressive interstitial pneumonia associated with amyopathic dermato myositis. Clin Rheum 2007; 26: 436-9.

5. Osman Y, Narita M, Kishi K. Case report: amyopathic dermatomyositis associated with transformed malignant lymphoma. Am J Med Sci 1996: 311: $240-2$

6. Whitmore SE, Watson R, Rosenshein NB et al. Dermatomyositis sine myositis: association with malignancy. J Rheumatol 1996; 23: 1010-5.

7. Cosnes A, Amaudric F, Gheradi R. Dermatomyositis without muscle weakness: long term follow up of 12 patients without systemic corticosteroids. Arch Dermatol 1995; 131: 1381-5.

Manuskriptet ble mottatt 27.10. 2008 og godkjent 7.5. 2009. Medisinsk redaktør Odd Terje Brustugun

\title{
Revmatologiske symptomer som varselsignal
}

Pasienten i kasuistikken ovenfor ble omfattende utredet for muskelsymptomer og hudsymptomer. Etter hvert ble det satt i gang behandling med glukokortikosteroider og til slutt stilte man den sjeldne diagnosen hypomyopatisk dermatomyositt. Selv om denne spesifikke diagnosen er svært sjelden, vil en assosiasjon av muskelog hudsymptomer føre til at differensialdiagnosen dermatomyositt vurderes.

Ved polymyositt og dermatomyositt er det observert økt forekomst av malignitet. Malignitet må også has i mente ved andre revmatologiske symptomer. Ved denne kasuistikken med omfattende differensialdiagnostiske vurderinger er det praktisk viktig å huske at kreftsykdom også kan gi symptomer som kan oppfattes som revmatologiske.

En pasient med malign sykdom kan utvikle autoimmune fenomener eller revmatisk sykdom som følge av autoantistoffdanning mot autoantigener (for eksempel onkoproteiner) eller som paraneoplastisk syndrom med et vidt spekter av kliniske syndromer (1).

Det anslås at $7-10 \%$ av kreftpasienter utvikler paraneoplastisk syndrom (1). Hos pasienter med dermatomyositt, polymyositt, vaskulitt og systemisk sklerose er det påvist økning i risiko for utvikling av malignitet. Høy alder, rask debut av hud- eller muskelsymptomer, og periungvalt erytem er assosiert med malignitet ved dermatomyositt (2). Hematologisk malignitet kan manifestere seg som kutan vaskulittsyndrom. Imidlertid kan også artritt være utløst av malignitet og kan manifestere seg som en symmetrisk polyartritt, slik som ved revmatoid artritt (3).

En litteraturgjennomgang viser at cancerartritt er sjeldent, men må påregnes som differensialdiagnose ved sen debut av terapirefraktær revmatoid artritt etter behandlingsforsøk med ikke-steroide antiflogistika eller glukokortikosteroider (4).

Muskelskjelettsymptomer kan være følge av svulstens direkte innvekst eller av spredning (4). Dersom dette ikke er tilfelle, foreligger det en paraneoplastisk tilstand. Selv om man antar at immunprosesser spiller en rolle i patogenesen, er den nøyaktige mekanismen ikke kjent. Bedring av leddsymptomer etter fjerning av tumor er godt dokumentert.

Å være årvåken for muligheten for underliggende cancer ved revmatologiske tilstander kan derved bidra til å diagnostisere malignitet tidligere. Et eksempel fra den praktiske hverdagen er at myelomatose kan manifestere seg initialt med leddsmerter. I utredning med serumelektroforese vil man kunne finne en M-komponent i gammaglobulinfrasjonen og ikke bare inflammatoriske forandringer.

Ved utredning av leddsmerter vil man ønske å identifisere tidlig artritt eller forhøyet risiko for å utvikle en kronisk form for leddgikt. Egne klinikker for tidlig artritt er også opprettet i Norge for å ivareta tidlige symptomer hos pasienter med artritt hvor aggressiv behandling er aktuelt (5)

Sjeldne bindevevssykdommer bør altså diagnostiseres tidlig, ikke minst fordi revmatologiske symptomer, inklusive leddsymptomer, kan være assosiert til malignitet.

\section{Till Uhlig}

till.uhlig@diakonsyk.no

Revmatologisk avdeling

Diakonhjemmet Sykehus

0319 Oslo
Oppgitte interessekonflikter: Ingen

\section{Litteratur}

1. Abu-Shakra M, Buskila D, Ehrenfeld M et al. Cancer and autoimmunity: autoimmune and rheu matic features in patients with malignancies. Ann Rheum Dis 2001: 60: 433-41.

2. Fardet L, Dupuy A, Gain M et al. Factors associated with underlying malignancy in a retrospective cohort of 121 patients with dermatomyositis. Medicine (Baltimore) 2009; 88: 91-7.

3. Stummvoll GH, Aringer M, Machold KP et al. Cancer polyarthritis resembling rheumatoid arthritis as a first sign of hidden neoplasms. Report of two cases and review of the literature. Scand J Rheumatol 2001; 30: 40-4.

4. Naschitz JE, Rosner I. Musculoskeletal syndromes associated with malignancy lexcluding hypertrophic osteoarthropathyl. Curr Opin Rheumatol 2008; $20: 100-5$.

5. Mjaavatten M, Haugen AJ, Helgetveit K et al. Pattern of joint involvement and other disease characteristics in 634 patients with arthritis of less than 16 weeks duration. J Rheumatol 2009; e-publisert 1.6.2009

Manuskriptet ble mottatt 22.5. 2009 og godkjent 4.6. 2009. Medisinsk redaktør Odd Terje Brustugun. 